\title{
The Development of Textbook Based Mind Mapping
}

\author{
Charles Fransiscus Ambarita \\ Economic Education Study \\ Program \\ State University of Medan \\ Medan, Indonesia
}

\author{
Dody Feliks Pandimun \\ Ambarita \\ Primary School Teacher \\ Education Study Program \\ State University of Medan \\ Medan, Indonesia \\ Dita Eka Pertiwi Sirait \\ Business Education Study \\ Program \\ State University of Medan \\ Medan, Indonesia
}

\author{
Rotua Sahat Pardamean \\ Simanullang \\ Office Administration \\ Education Study Program \\ State University of Medan \\ Medan, Indonesia
}

\begin{abstract}
The purpose of this study was to determine the feasibility and effectiveness of Learning Planning textbook based mind mapping that was developed. This type of research is research and development with 4D model. The subjects of this research are material expert, media expert, and test subjects. The data collection techniques are validation sheets and tests. The feasibility result of material expert's assessment on the component aspect with a total percentage of $91.66 \%$ is included in very good criteria and feasibility assessment of material substance with a total percentage of $94.4 \%$ is in very good criteria while the result of validation based on media experts with total average score of 87 with very good criteria. The use of textbook based mind mapping in the Lesson Planning course is effective for improving college student learning outcomes with an average of 84.06 with very good criteria.
\end{abstract}

Keywords: Development, Learning Planning Textbook Based Mind Mapping, Feasibility, Effectiveness

\section{INTRODUCTION}

State University of Medan is one of the higher education institutions in Indonesia that has the responsibility to produce competitive graduates in the form of quality teachers. The Faculty of Economics as an integral part of Medan plays a role in the success of Medan's mission to answer challenges, opportunities, community demands, and prepare professional and competitive teacher candidates.

This quality graduate profile can be achieved by improving college students' creative thinking skills which are also part of life skills. The ability to think is an important competency that must be possessed by college students and is directed towards educational goals that are broadly based, useful, tangible, meaningful in preparing college students to face future challenges, especially preparation for the industrial revolution 4.0. The quality of learning is measured through mastery of learning, namely from the results and the learning process carried out.

Based on the results of observation made in the Lesson Planning course about the cause of the low mastery of college students in understanding the Lesson Planning course material, it is suspected that there is a lack of literature or references related to Learning Planning material. College students are only guided by textbook that have been used by lecturers without any other learning resources. In addition, college students are less skilled in finding new ideas to solve a problem, college students are also less enthusiastic about asking questions or answers to the problems discussed, less creative and lack of variety in conveying the results of activities.

The results of this observation were further confirmed when discussing with the lecturers of the Lesson Planning course. The results of the discussion show that college students have not been able to think creatively when solving a problem with a different point of view and college students tend to be passive in learning so they cannot explore their creative ideas. The low creative thinking ability of college students certainly has direct implications for the mastery of the Lesson Planning course. The lesson planning course is not fully and thoroughly mastered by college students. This can be seen from the final score of college students in the semester last year.

Optimization efforts need to be done, namely developing learning media, especially the development of textbooks that can improve college students' creative thinking skills. The textbook that has been used so far cannot explore college students' creative thinking skills and mastery of Learning Planning courses. The development of Learning Planning textbook based mind mapping needs to be held to improve college students' creative thinking skills and mastery of Learning Planning materials. Jensen and Makowitz argue that mind mapping is a way of visualizing verbally into visuals or images which can make it easier to store, strengthen, and recall information that has been learned [1]. Furthermore, Edward explains mind mapping is a very effective and 
efficient method to store and retrieve data or information from or to the brain. This system works according to the natural workings of the human brain, so that the potential and capacity of the human brain can be optimal [2]. Then, Zampetakis and Tsironis stated that mind mapping is a way that can make a boring task fun and interesting, so that it can optimize concentration and memory. With mind mapping, the student's ability to be active and remember will increase [3]. Meanwhile, Windura explained simply that Mind map is a graphic technique that allows a person to explore all the abilities of the brain for the purposes of thinking and learning [4]. Mind maps are designed to map all knowledge completely and thoroughly. Mind maps are one of the easiest ways to put information into the brain and take information out of the brain. In addition, mind maps can also develop the work potential of the two hemispheres of the brain both in writing and verbally by using a combination of colors, symbols, shapes and so on so that the brain can easily absorb the information received. The use of this Learning Planning textbook will help college students activate their whole brain, look for a chronological order of a problem, focus their thoughts on a theme and provide a clear picture of a lecture material so that they can improve their creative thinking skills and achieve mastery of Learning Planning courses.

Based on the background of the problems described above, the problem that becomes the study material in this research are how is the feasibility textbook based mind mapping developed in the Lesson Planning course in the Department of Economics Education, Faculty of Economics, State University of Medan? and how is the effectiveness textbook based mind mapping developed in the Lesson Planning course in the Department of Economics Education, Faculty of Economics, State University of Medan? The purposes of this study ware to determine the feasibility and effectiveness of the textbook based mind mapping developed in the Lesson Planning course in the Department of Economics Education, Faculty of Economics, State University of Medan.

\section{METHOD}

This study is a research and development type. Putra defines research and development as a research method that is intentionally, systematic, aimed/ directed to find, formulate, improve, develop, produce, test the effectiveness of products, models, methods/ strategies/ methods, services, certain procedures that are superior, new, effective, efficient, productive and meaningful [6]. The product produced in this study is a textbook based mind mapping in the Lesson Planning course in the Economic Education study program, Faculty of Economics, State University of Medan.

This study uses 4D model. Thiagarajan in Sugiyono said that the development of 4D model consists of 4 main stages, namely: 1) define, 2) design, 3) develop, and 4) disseminate [7]. This research was only carried out until the develop stage, the disseminate stage was not carried out due to cost and time constraints.
This study uses validation sheets and tests as instruments of collecting data. Validation sheets are used to obtain data about feasibility of the developed product and tests are used to obtain data about effectiveness of the developed product. The research data were analyzed to determine feasibility and effectiveness of the developed product. The feasibility of the developed product can be seen from the assessments of material expert and media expert. The effectiveness of the developed product can be seen from the pretest and posttest answered by the third semester B class 2019 college students in the Economic Education study program, Faculty of Economics, State University of Medan.

\section{RESULTS}

\subsection{Define Stage}

The define stage is carried out by conducting curriculum analysis, concept analysis, college student analysis and needs analysis. The steps of this define stage are as follows:

Curriculum analysis

Curriculum analysis is done by analyzing Competency Standard and Basic Competencies in the Lesson Planning course. The results of the analysis of Competency Standard and Basic Competencies become the formulation of learning indicators. The formulation of the learning indicators are as follows:

1. Understand the nature of learning planning,

2. Understand the learning system design model oriented to the achievement of goals,

3. Understand the planning of learning programs,

4. Understand competency development as a learning objective,

5. Understand learning strategies,

6. Design learning activities,

7. Understand the development of learning resources and learning media,

8. Understand the technique of preparing and implementing the evaluation of learning outcomes.

The learning indicators that have been developed are formulated as the basis for learning objectives. The learning objectives that must be mastered by college students in the learning process are set as follows:

1. College students are expected to be able to understand the nature of learning planning including definition, importance, benefits, functions, criteria and steps for making learning planning,

2. College students are able to understand the learning system design model oriented to the achievement of goals including: definition of curriculum based competency, characteristics of curriculum based competency, expected competencies in learning, syllabus development and implementation, and competency achievement instructional system design model,

3. College students are expected to be able to plan learning programs including: the nature of learning planning, development of learning programs, syllabus, annual program planning, and semester program planning, 
4. College students are able to develop the competence of learning objectives including: the nature of learning objectives, the hierarchy of educational and learning objectives, classification of learning objectives, and the format of designing learning objectives,

5. College students are able to develop learning strategies including: definition of learning strategies, approaches, strategies, methods, techniques and learning models, principles of using learning strategies, and learning organizing strategies,

6. College students are expected to be able to design learning activities including: the need for preparation of lesson plan, definition and function of lesson plan, and components of lesson plan,

7. College students are able to develop learning resources and media including: utilization of learning resources, choosing learning resources, learning media, benefits and functions of learning media, use of learning media, classification and types of learning media, characteristics of learning media, and selection and use of learning media,

8. College students are able to design techniques for the preparation and implementation of the evaluation of learning outcomes including: steps for preparing the evaluation of learning outcomes, planning for the preparation of evaluation of learning outcomes, writing items for evaluating learning outcomes, strengths and weaknesses of essay test, use of essay test, classification of essay test, and implementation techniques evaluation of learning outcomes.

\section{Concept analysis}

Concept analysis aims as the basis for the main concepts that must be mastered by college students in the learning process. In the concept analysis, the identification and formulation of the main concepts will be compiled in the material in the textbook based mind mapping. Based on the learning indicators and learning objectives, the main concepts are determined as follows:

1. Definition, importance, benefits, functions, criteria and steps for making learning planning,

2. Definition of curriculum based competency, characteristics of curriculum based competency, expected competencies in learning, syllabus development and implementation, and competency achievement instructional system design model,

3. The nature of learning planning, development of learning programs, syllabus, annual program planning, and semester program planning,

4. The nature of learning objectives, the hierarchy of educational and learning objectives, classification of learning objectives, and the format of designing learning objectives,

5. Definition of learning strategies, approaches, strategies, methods, techniques and learning models, principles of using learning strategies, and learning organizing strategies,

6. The importance of preparing lesson plan, understanding and function of lesson plan, as well as the components of lesson plan,

7. Utilization of learning resources, choosing learning resources, learning media, benefits and functions of learning media, use of learning media, classification and types of learning media, characteristics of learning media, and selection and use of learning media,

8. Steps for preparing the evaluation of learning outcomes, planning for the preparation of evaluation of learning outcomes, writing items for evaluating learning outcomes, strengths and weaknesses of essay test, use of essay test, classification of essay test, and implementation techniques evaluation of learning outcomes.

College students analysis

College students analysis was conducted to determine the characteristics of college students. Characteristics of college students include age, motivation, background knowledge of college students, academic abilities, and social skills. Furthermore, psychological changes that occur such as efforts to find identity, future aspirations begin to arise, freedom to do something. Some college students have started to be able to think abstractly and be scientific. Thus, they are able to understand abstract meaning and principles based on formal concepts and theories, and can formulate hypotheses and think systematically in dealing with a problem.

Needs analysis

The needs analysis was carried out by distributing questionnaires to the third semester 2019 college students in the Economic Education study program, Faculty of Economics, State University of Medan as many as 30 persons by describing the definition of textbook based mind mapping firstly in the questionnaire in order to have an overview of the questions in the questionnaire submitted. The summary of the needs analysis data can be seen in the following table.

Table 1. The Summary of Needs Analysis Data

\begin{tabular}{|l|l|l|l|l|}
\hline No. & \multicolumn{1}{|c|}{ Statement } & Answer & Frequency & Percentage \\
\hline 1 & $\begin{array}{l}\text { Know Learning } \\
\text { Planning textbook } \\
\text { based mind mapping }\end{array}$ & Yes & 2 & $6,66 \%$ \\
\cline { 3 - 5 } & No & 28 & $93,33 \%$ \\
\hline 2 & $\begin{array}{l}\text { Use Learning } \\
\text { Planning textbook } \\
\text { based mind mapping }\end{array}$ & Yes & 0 & $0 \%$ \\
\cline { 3 - 5 } 3 & $\begin{array}{l}\text { Need Learning } \\
\text { Planning textbook } \\
\text { based mind mapping }\end{array}$ & Yes & 30 & $100 \%$ \\
\cline { 3 - 5 } & & No & 0 & $0 \%$ \\
\hline
\end{tabular}

Based on the table, it can be concluded that the development of textbook based mind mapping is needed by college students in the learning process for the Lesson Planning course.

\subsection{Design Stage}

At this stage, the researcher designed and compiled a textbook based mind mapping. The draft product specifications are as follows:

Formulation of Learning Objectives

The formulation of learning objectives is arranged specifically and systematically based on curriculum provisions. The formulation of learning objectives starts from setting 
competency standard, basic competencies and indicators of achieving learning objectives. From the indicators formulated learning objectives that must be mastered by college students. The learning objectives of the cognitive and psychomotor domains are formulated based on competency standard, basic competencies and indicators that have been determined by the curriculum.

\section{Description of the Contents of Textbook}

The description of the material or content of teaching materials refers to the Indonesian National Qualifications Framework (KKNI). The curriculum which initially refers to the achievement of competencies becomes referring to learning outcomes.

\subsection{Develop Stage}

The development phase includes expert validation and testing of textbook based mind mapping to see the feasibility and effectiveness.

Feasibility of the developed product

The textbook that has been compiled were validated by 2 (two) validators, namely 1 expert in the field of Learning Planning and 1 learning design expert. Material expert validation is intended to obtain information on the quality of textbook based mind mapping that has been developed, while media expert validation is carried out to improve the quality of the developed textbook. The results of the assessments from material and media expert can be seen in the following table.

Table 2. Material Expert's Assessment on Component Aspect

\begin{tabular}{|c|c|c|}
\hline $\begin{array}{l}\text { Assessment } \\
\text { aspect }\end{array}$ & Assessment indicators & Score \\
\hline \multirow[t]{10}{*}{ Component } & $\begin{array}{l}\text { I. Interesting title and in } \\
\text { accordance with the content }\end{array}$ & 4 \\
\hline & $\begin{array}{l}\text { 2. Contains core } \\
\text { competencies and basic } \\
\text { competencies }\end{array}$ & 4 \\
\hline & $\begin{array}{l}\text { 3. Compatibility between } \\
\text { indicators and basic } \\
\text { competencies }\end{array}$ & 3 \\
\hline & $\begin{array}{l}\text { 4. Learning objectives are in } \\
\text { accordance with core } \\
\text { competencies and basic } \\
\text { competencies }\end{array}$ & 3 \\
\hline & $\begin{array}{l}\text { 5. } \begin{array}{l}\text { Demonstrate the benefits } \\
\text { gained by the learners }\end{array} \\
\end{array}$ & 4 \\
\hline & $\begin{array}{l}\text { 6. In accordance with the } \\
\text { learning objectives }\end{array}$ & 4 \\
\hline & $\begin{array}{l}\text { 7. There is perception and } \\
\text { material enrichment }\end{array}$ & 4 \\
\hline & $\begin{array}{l}\text { 8. There are examples of } \\
\text { questions that are in } \\
\text { accordance with the } \\
\text { learning objectives }\end{array}$ & 4 \\
\hline & $\begin{array}{l}\text { 9. Stimulate college students } \\
\text { to develop knowledge }\end{array}$ & 4 \\
\hline & $\begin{array}{l}\text { 10. There are exercises / tests / } \\
\text { stimuli that are in } \\
\text { accordance with the } \\
\text { learning objectives that }\end{array}$ & 3 \\
\hline
\end{tabular}

\begin{tabular}{|c|c|}
\hline $\begin{array}{l}\text { allow college students to } \\
\text { master the expected basic } \\
\text { competencies }\end{array}$ & \\
\hline $\begin{array}{l}\text { 11. There is a list of actual } \\
\text { references from books, } \\
\text { print/electronic media, and } \\
\text { scientific journals }\end{array}$ & 3 \\
\hline $\begin{array}{l}\text { 12. Compliance with reference } \\
\text { writing rules }\end{array}$ & 4 \\
\hline Total Score & 44 \\
\hline Percentage & $91.66 \%$ \\
\hline Criteria & $\begin{array}{l}\text { Very } \\
\text { Good }\end{array}$ \\
\hline
\end{tabular}

Based on the table, it can be seen that the result of the material expert's assessment on the component aspect of textbook based mind mapping developed were declared very good with percentage of $91.66 \%$.

Table 3. Media Expert's Assessment on Material Substance Aspect

\begin{tabular}{|c|c|c|}
\hline $\begin{array}{c}\text { Assessment } \\
\text { aspect }\end{array}$ & Assessment indicators & Score \\
\hline \multirow[t]{11}{*}{$\begin{array}{c}\text { Material } \\
\text { Substance }\end{array}$} & $\begin{array}{ll}\text { 1. In accordance with } \\
\text { scientific principles }\end{array}$ & 4 \\
\hline & 2. $\quad$ Tested & 4 \\
\hline & 3. $\quad$ Factual (based on facts) & 4 \\
\hline & 4. Logical/ rational & 3 \\
\hline & 5. Completeness of materials & 3 \\
\hline & 6. Exploration/ development & 4 \\
\hline & $\begin{array}{l}\text { 7. Collaboration with other } \\
\text { materials/ other subjects }\end{array}$ & 4 \\
\hline & 8. Descriptive/ imaginative & 3 \\
\hline & 9. $\begin{array}{l}\text { Actualization (in terms of } \\
\text { material) }\end{array}$ & 4 \\
\hline & $\begin{array}{l}\text { 10. Innovative (bringing up } \\
\text { new things) }\end{array}$ & 4 \\
\hline & $\begin{array}{l}\text { 11. Standard language and } \\
\text { can be understood }\end{array}$ & 4 \\
\hline \multicolumn{2}{|r|}{ Total Score } & 41 \\
\hline \multicolumn{2}{|r|}{ Percentage } & $94.54 \%$ \\
\hline \multicolumn{2}{|r|}{ Criteria } & $\begin{array}{l}\text { Very } \\
\text { Good }\end{array}$ \\
\hline
\end{tabular}

Based on the table, it can be seen that the result of the material expert's assessment on the material substance aspect of textbook based mind mapping developed were declared very good with percentage of $94.54 \%$.

Table 4. Media Expert's Assessment

\begin{tabular}{|l|l|l|l|}
\hline Components & \multicolumn{1}{|c|}{ Indicators } & $\begin{array}{c}\text { Average } \\
\text { Score }\end{array}$ & Criteria \\
\hline A. Textbook & $\begin{array}{l}\text { 1. Textbook size } \\
\text { conformity with }\end{array}$ & 4 & Very \\
\hline
\end{tabular}




\begin{tabular}{|c|c|c|c|}
\hline \multirow[t]{2}{*}{ Size } & \multicolumn{2}{|l|}{$\begin{array}{l}\text { ISO standards (A4, } \\
\text { A5, and B5) }\end{array}$} & Good \\
\hline & $\begin{array}{l}\text { 2. Size suitability } \\
\text { with the content of } \\
\text { the textbook }\end{array}$ & 4 & $\begin{array}{l}\text { Very } \\
\text { Good }\end{array}$ \\
\hline \multirow[t]{10}{*}{$\begin{array}{l}\text { B. Textbook } \\
\text { Design } \\
\text { (Cover) }\end{array}$} & $\begin{array}{l}\text { 3. The appearance } \\
\text { of the layout } \\
\text { elements on the } \\
\text { front, back and back } \\
\text { covers } \\
\text { harmoniously has } \\
\text { rhythm and unity } \\
\text { and is consistent. }\end{array}$ & 3 & Good \\
\hline & $\begin{array}{l}\text { 4. Shows a good } \\
\text { center of view. }\end{array}$ & 3 & Good \\
\hline & $\begin{array}{l}\text { 5. The color of the } \\
\text { elements of the } \\
\text { layout are } \\
\text { harmonious and } \\
\text { clarify the function }\end{array}$ & 3 & Good \\
\hline & $\begin{array}{l}\text { 6. The composition } \\
\text { and size of the } \\
\text { layout elements } \\
\text { (title, author, } \\
\text { illustration, logo, } \\
\text { etc.) are } \\
\text { proportional, } \\
\text { balanced, and in } \\
\text { rhythm with the } \\
\text { layout of the } \\
\text { content (according } \\
\text { to the pattern) }\end{array}$ & 3 & Good \\
\hline & \multicolumn{3}{|c|}{ Typography cover } \\
\hline & $\begin{array}{l}\text { 7. The font size for } \\
\text { the title of the } \\
\text { textbook is more } \\
\text { dominant and } \\
\text { proportional than } \\
\text { the size of the } \\
\text { textbook, the name } \\
\text { of the author. }\end{array}$ & 3 & Good \\
\hline & $\begin{array}{l}\text { 8. The color of the } \\
\text { textbook title } \\
\text { contrasts with the } \\
\text { background color }\end{array}$ & 4 & $\begin{array}{l}\text { Very } \\
\text { Good }\end{array}$ \\
\hline & $\begin{array}{l}\text { 9. Don't use too } \\
\text { many typeface } \\
\text { combinations }\end{array}$ & & \\
\hline & \multicolumn{3}{|c|}{ Illustration of a textbook cover } \\
\hline & $\begin{array}{l}\text { 10. Describe the } \\
\text { content/teaching }\end{array}$ & 4 & Very \\
\hline
\end{tabular}

\begin{tabular}{|c|c|c|c|}
\hline & $\begin{array}{l}\text { materials and reveal } \\
\text { the character of the } \\
\text { object }\end{array}$ & & Good \\
\hline & $\begin{array}{l}\text { 11. Shape, color, } \\
\text { size, proportion of } \\
\text { the object according } \\
\text { to reality }\end{array}$ & 4 & $\begin{array}{l}\text { Very } \\
\text { Good }\end{array}$ \\
\hline $\begin{array}{l}\text { C. Textbook } \\
\text { Content } \\
\text { Design }\end{array}$ & \multicolumn{3}{|c|}{ Layout Consistency } \\
\hline & $\begin{array}{l}\text { 12. Consistent } \\
\text { placement of layout } \\
\text { elements based on } \\
\text { patterns }\end{array}$ & 3 & Good \\
\hline & $\begin{array}{l}\text { 13. The separation } \\
\text { between paragraphs } \\
\text { is clear }\end{array}$ & 3 & Good \\
\hline & \multicolumn{3}{|c|}{ Harmonic Layout Elements } \\
\hline & $\begin{array}{l}\text { 14. Print area and } \\
\text { proportional } \\
\text { margins }\end{array}$ & 4 & $\begin{array}{l}\text { Very } \\
\text { Good }\end{array}$ \\
\hline & $\begin{array}{l}\text { 15. The margins of } \\
\text { two pages side by } \\
\text { side are } \\
\text { proportional }\end{array}$ & 3 & Good \\
\hline & $\begin{array}{l}\text { 16. Spacing } \\
\text { between text and } \\
\text { illustration is } \\
\text { appropriate }\end{array}$ & 3 & Good \\
\hline & $\begin{array}{l}\text { 17. Chapter titles, } \\
\text { subtitles, } \\
\text { illustrations, and } \\
\text { picture captions do } \\
\text { not interfere with } \\
\text { understanding }\end{array}$ & 4 & $\begin{array}{l}\text { Very } \\
\text { Good }\end{array}$ \\
\hline & \multicolumn{3}{|c|}{ Typography } \\
\hline & $\begin{array}{l}18 . \text { Do not use too } \\
\text { many typefaces. }\end{array}$ & 4 & $\begin{array}{l}\text { Very } \\
\text { Good }\end{array}$ \\
\hline & $\begin{array}{l}\text { 19. The use of letter } \\
\text { variations (bold, } \\
\text { italic, all capital, } \\
\text { small capital) is not } \\
\text { excessive }\end{array}$ & 4 & $\begin{array}{l}\text { Very } \\
\text { Good }\end{array}$ \\
\hline & $\begin{array}{l}\text { 20. The typeface is } \\
\text { in accordance with } \\
\text { the content material }\end{array}$ & 4 & $\begin{array}{l}\text { Very } \\
\text { Good }\end{array}$ \\
\hline & $\begin{array}{l}21 . \text { The layout of } \\
\text { the text is between }\end{array}$ & 3 & Good \\
\hline
\end{tabular}




\begin{tabular}{|c|c|c|c|}
\hline & $45-75$ characters & & \\
\hline & \multicolumn{3}{|c|}{ Illustration of Contents } \\
\hline & $\begin{array}{l}\text { 22. Able to reveal } \\
\text { the meaning of the } \\
\text { object }\end{array}$ & 3 & Good \\
\hline & $\begin{array}{l}23 . \text { Accurate and } \\
\text { proportional shape } \\
\text { in accordance with } \\
\text { reality }\end{array}$ & 4 & $\begin{array}{l}\text { Very } \\
\text { Good }\end{array}$ \\
\hline & $\begin{array}{l}\text { 24. Presentation of } \\
\text { the whole } \\
\text { illustration }\end{array}$ & 3 & Good \\
\hline & $\begin{array}{l}\text { 25. Creative and } \\
\text { dynamic }\end{array}$ & 3 & Good \\
\hline Total a & verage score & 87 & $\begin{array}{l}\text { Very } \\
\text { Good }\end{array}$ \\
\hline
\end{tabular}

Based on the table, it can be seen that the result of the media expert's assessment on the textbook size, textbook design (cover) and textbook content design aspect of textbook based mind mapping developed were declared very good with total average score of 87 .

Effectiveness of the developed product

The effectiveness of textbook based mind mapping was tested on class B college students in the third semester of Class 2019 Economic Education Study Program, Faculty of Economics, State University of Medan using tests. The tests carried out are classified into 2 types of tests, namely pretest and posttest. The results of the data recapitulation obtained from the pretest and posttest are described in the following table.

Table 5. Pretest and Posttest Results

\begin{tabular}{|c|c|c|}
\hline No & Pretest & Posttest \\
\hline 1 & 60 & 85 \\
\hline 2 & 60 & 80 \\
\hline 3 & 45 & 85 \\
\hline 4 & 60 & 90 \\
\hline 5 & 55 & 95 \\
\hline 6 & 60 & 90 \\
\hline 7 & 55 & 85 \\
\hline 8 & 50 & 80 \\
\hline 9 & 65 & 85 \\
\hline 10 & 50 & 75 \\
\hline
\end{tabular}

\begin{tabular}{|c|c|c|}
\hline 11 & 65 & 90 \\
\hline 12 & 55 & 85 \\
\hline 13 & 55 & 80 \\
\hline 14 & 50 & 75 \\
\hline 15 & 60 & 80 \\
\hline 16 & 65 & 80 \\
\hline 17 & 60 & 85 \\
\hline 18 & 55 & 75 \\
\hline 19 & 70 & 95 \\
\hline 20 & 55 & 85 \\
\hline 21 & 60 & 95 \\
\hline 22 & 50 & 80 \\
\hline 23 & 55 & 75 \\
\hline 24 & 55 & 95 \\
\hline 25 & 65 & 80 \\
\hline 26 & 60 & 80 \\
\hline 27 & 65 & 95 \\
\hline 28 & 55 & 90 \\
\hline 29 & 65 & 90 \\
\hline 30 & 60 & 75 \\
\hline 31 & 50 & 80 \\
\hline 32 & 60 & 75 \\
\hline Total & 1850 & 2690 \\
\hline Average & 57.81 & 84.06 \\
\hline
\end{tabular}

The table shows that the pretest of college students obtained a total of 1850 with an average of 57.81 being in the deficient criteria, while the posttest or in other words the test carried out after the application of textbook based mind mapping obtained a total of 2690 with an average 84.06 on the very good criteria. Based on the table, it can be concluded that the average score obtained by college students has increased where after using textbook based mind mapping, it was 84.06 compared to 57.81 before using textbook based mind mapping. 


\section{CONCLUSIONS}

Based on the feasibility result of material expert's assessment of component aspect that was developed, it was declared "very good" with a total average percentage of $91.66 \%$. and material expert's assessment on material substance aspect is considered "very good" with a total average percentage of 94.54\%. While the result of media expert's assessment concluded that the learning media developed were in the "very good" criteria with a total average score of 87 . In terms of effectiveness, the use of textbook based mind mapping is effective for improving college student learning outcomes with a total score of 2,690 with an average of 84.06 which is included in the "very good" criteria.

\section{ACKNOWLEDGMENT}

Special thanks to Prof. Dr. Baharuddin, M.Pd. for the funds that have been given through the Community Service Institute of State University of Medan, may you always be blessed by God Almighty in your work, health, long life and all elements of life.

\section{REFERENCES}

[1] Markowitz, K.\& Jensen, E. 2002. Otak Sejuta Gigabyte. Bandung: Kaifa.

[2] Edward, Caroline. 2009. Mind Mapping untuk Anak Sehat dan Cerdas.Yogyakarta: Sakti.

[3] Zampetakis, Leonidas A and Tsironis, Loukas. 2007. Creativity Development in Engineering Education: The Case of Mind Mapping. Journal of Management Development.

[4] Windura, Susanto. 2008. Mind Map Langkah Demi Langkah. Jakarta: Gramedia.

[5] Putra, Nusa. 2012. Research \& Development Penelitian dan Pengembangan: Suatu Pengantar. Jakarta: Rajawali Press.

[6] Sugiyono. Metode Penelitian Kuantitatif, Kualitatif, dan R\&D. Bandung: Alfabeta; 2013. 